\title{
Two Stages/Spaces in Puerto Rican Theater: A Report From the Field
}

\section{Jade Power}

Although the best times for watching theater in Puerto Rico are often during the various theater festivals that take place throughout the fall and spring, theater activity seemed pleasantly robust this last July, at least on some fronts. My past theater research on the island has generally been focused on "alternative" theater, or "el otro teatro," and the spaces in which this takes place. I am glad to report that this movement of experimental performance continues, both within and outside of the confines of designated theatrical spaces. Even as the Teatro Diplo in Rio Piedras closed due to small audiences and lack of sufficient local support, members of PACA (Proyecto Artístico, Cultural y Académico) are remodeling the same building to house the Sala Teatro Beckett. The new space promises to host a café and film showings, as well as new performances by emerging artists. Simultaneously, a couple of blocks away, in the same bustling Río Piedras business district, Teatro Estudio Yerbabruja, hosted its $10^{\text {th }}$ annual Mixta con todos, a potpurri, or "mixed plate," that included solo performance, masks, multi-media, live music, and an array of artists that reflected a diversity in age, experience and artistic vision. However, the most gratifying theatrical experience during my brief visit to the island, and certainly the most promising in terms of talent, social import, and originality, was the play Policias, Vaqueros, Burócratas y Piratas presented as "teatro de urgencia" by La Perilla y El Kibutz, a collective of young artists.

We were told that the performance would be starting at 11:00pm on Wednesday night. It had recently rained and most of the plastic chairs in the small back patio area of the newest Rio Piedras hot spot Il Jazz Club were still wet. It was just about 11:00 when we got there, the front room hosted a Latin jazz quartet and in the back just a handful of people were standing 
around talking, smoking and drinking. I managed to score a chair, dry it and made sure no one else took it while I bought some empanadas and tortilla española sold by a cheerful argentina under a big umbrella who informed me that the proceeds were for the actors. I noted that we had not paid to enter the club, nor had anyone charged admission in the back patio. I was not quite sure what to expect from the upcoming performance, at best some amateurish political theater with perhaps a couple of especially talented individuals who would carry the show.

Several empanadas later and nearing midnight, the patio was getting packed even though there was still no sign that the show was going to start. I was glad for the one chair that my partner and I kept taking turns with as 60 or more people crowded into the tiny space. What would be the playing space, a small area of about 150 square feet, was however respected and kept empty. Although the chairs were not positioned in rows they were assembled in a clump on one side of the space, all facing in the same general direction, and there were also a few clip lights hanging on the 8 foot walls that helped to further frame the stage area.

The opening scene immediately captivated the audience, and remains a clear image in my mind. The seven actors pushed their way through the crowd in the back and filed onto the stage, lining up facing the audience. Dressed as policemen and policewomen they began harassing the audience, just inches in front of us, pointing at us, accusing us, preparing to write us citations, telling us that we could not do whatever it was we were doing. They began speaking one at a time and later started interrupting each other, until their voices eventually blended into a cacophony of shouts. Their bodies were tense with the gestures of authoritative intimidation. This whole sequence, although at times uncomfortable to watch, was hilarious and was met with gleeful laughter from the audience once the initial uncertainty of being so impertinently accused was assuaged by the satirical quality of the language. True to reality, some of the actors would even flirt with the audience members, preening like roosters in their fitted uniforms, underscoring the link between a sexualized dominance and the objectifying gaze of power. The language and the acting were both so realistic in this sequence, reminding me of any number of instances dealing with the often over-inflated egos of police officers in Puerto Rico and elsewhere. At the same time however, watching these actors perform these roles with such precision served to emphasize the way in which the power enacted by authority is never more than a carefully crafted performance. 
A collaboratively created ensemble piece, written by Rojo Robles Mejías and co-directed by Robles Mejías and Pedro Leopoldo Sánchez Tormes, the play was dramaturgically sound even if at times it was difficult to follow because events and characters moved and changed so quickly. As the police officers later became cowboys and cowgirls in a fictitious, nameless Saloon of the American West's past, the importance of the storyline receded in the face of the underlying message about a resistance to authority, in this case quite violent. This theme was further developed back in contemporary Puerto Rico, when a building of office workers (los burócratas) was forced to evacuate in a panic due to several simultaneous events: the loss of all data from computers because of a system-wide virus, a bomb threat, riots in the streets of San Juan and an approaching dark ship (presumably terrorists) off the coast. The ensuing chaos again pointed to the central issues of rules, laws, permissions and authority as well as to the irrational fear of the unknown, of the possibility of change. Furthermore the silent, looming presence of the US federal government posed another source of dominance, not only politically but also culturally, when North American cultural tourism was suggested as a potential solution to the current economic crisis. Finally, the play ended with the actors transforming into pirates, into the agents of change and upheaval, the archetypal outlaws and ghosts of a Caribbean past, who live beyond the reach of institutional power. Holding mast-like poles with cloth, the actors created the final image of the dark ship in full sail, as they repeated over and over, "no necesitamos permiso para estar vivos, repetimos, no necesitamos permiso para estar vivos" conceptually expanding the notion of government control and policing to include human existence itself, and actively resisting this constant surveillance by claiming their rights as artists to create theater.

I was surprised when the play ended that nearly an hour had passed, even though sitting on my partner's lap was not the most comfortable position for watching a play. What I had just witnessed was a group of very talented performers, in an extremely thought-provoking, intelligently written and creatively staged play that managed to grapple with questions of belonging, authenticity, and the Caribbean history of colonial oppression that continues to be enacted on the minutest levels. Not only this, but the performers' occupation of the back patio of Il Jazz Club, a non-traditional performance space, performatively enacted their resistance to needing institutional approval. While certainly Il Jazz Club had granted the teatreros permission, as had El Nuyorican Café, a nightclub in Old San Juan where the play was also performed on every Friday in the month of July, it was refreshing to see 
theater that was strong and riveting despite poor seating conditions, chatty audience members, and little to no technical equipment. The July run of this play also included one outdoor performance in a plaza Old San Juan on "noche de galeria," when one Tuesday a month all of the galleries open late at night and the streets are filled with festivities. I have no doubt that this play would work in any setting that it is produced and in fact a street performance would be particularly conducive to enacting the play's central themes since at one point, some artist characters were cleared away from the street by the "police" for failing to have a permission to perform in public spaces. The young artists from La Perilla y El Kibutz are the piratas of today's Puerto Rican theater, doubtlessly indebted to the resources of others but richly endowed with their own talents and their will to create on the margins, by no one else's rules.

By contrast, a couple of weeks later I went with a family friend to see one of René Marqués' more obscure plays, Mariana o el alba at the Centro de Bellas Artes in none other than the Sala Teatro René Marqués. I decided to go because it had been a long time since I had seen a play at Bellas Artes and because I had never read or seen Mariana o el alba and I was curious. The discounted tickets at $\$ 20$ each bought us seats towards the back of the balcony. Overall, the play fulfilled, but did not surpass, my expectations, leaving me with a lukewarm reaction. There was some quality acting, especially by the legendary Cordelia González who played the lead, although Braulio Castillo Jr., was disappointing and difficult to hear. The set, created by the accomplished visual artist Antonio Martorell, was a stunningly beautiful oval disc center stage with gold colored floating branches above that created a sense of isolation in which the characters were living. Interestingly, according to the program, this was only the play's third professional production, directed by Pablo Cabrera who also directed the 1965 premiere. There was nothing extraordinary or terrible about this performance as it followed the standard, yet masterfully crafted melodramatic plot typical of Marqués' plays, replete with beautiful poetry, imagery and nationalistic fervor. However, I bring up this experience because it highlights a point I made above about performatively enacting resistance and serves as a nice bookend for what I perceive is happening theatrically in Puerto Rico.

In this play Marqués tells the story of the historical and much celebrated figure of Mariana Bracetti who sewed, as well as helped to conceptualize, the very first Puerto Rican flag, today commonly known as la bandera de Lares, the predecessor to the current official flag. Bracetti was the wife of a nationalist landowner who assisted in the plans for El Grito de 
Lares, the 1868 armed uprising for Puerto Rican independence. (Needless to say this is a very pro-Independence play.) About half way through the play when Mariana unfurled her creation, the audience erupted in spontaneous applause. My friend leaned over to me and said, "ay si pero nunca hacen nada." Between the multiple acts, there were supertitles projected onto the closed curtain, describing the lapse of time, the location, and sometimes the passage of events. At the end of the play, after the failure of the insurgence, as Mariana awaits the arrival of the Spanish republicanos who will take her to prison, the supertitles were once again projected. This time they recounted the lives of the historical characters after the closing of the play, stating what happened to them relative to Puerto Rico's political situation. The final slide read something along the lines of: "2009: Puerto Rico todavía no es libre," at which point the audience began applauding, giving the performance, or perhaps the ideology set forth by the play, a standing ovation.

What I find interesting about looking at the ending moment of this production alongside that of the play I saw at Il Jazz Club is that they both signal a dissatisfaction with the present political situation in Puerto Rico, one that is rooted in a frustration with its continued colonial status. However, while the production of Marqués' play expressed this sentiment through the traditional symbols of the flag, the imprisoned political activist, the failed, but perhaps still achievable, promise of a nation, Policias, Vaqueros, Burócratas y Piratas focused more on the daily, individual manifestations of this historical legacy. These artists question and challenge the controlling and disciplining of human bodies, of human actions, within the milieu of present day political and social realities. Their understanding of resistance supersedes the independence-statehood continuum in an incredibly refreshing manner. In many ways this contrast reflects what some consider to be the weakness of today's independence movements; a disconnect between the material reality of the majority of Puerto Ricans and political ideology. While Mariana o el alba, published in 1968, is certainly dated, the audience response ("si pero nunca hacen nada") also follows this now stagnant trajectory of celebrating the idea of resistance without performing resistance. Of course I have no knowledge of the individual audience members' political activism or involvement and I am thus generalizing in making this point. However, the fact remains that despite the proliferation of flags, machetes inscribed with "Coño, despierta Boricua," and cultural productions that demonize the colonial oppressor, little progress has been made in improving the quality of life for Puerto Ricans, either through an independence movement or otherwise. 
The performance at Bellas Artes was not however, void of political import despite its traditionalist approach. It deserves mentioning that this production of Mariana o el alba was performed in the face of the current pro-statehood government, (probably the most politically and socially conservative in commonwealth history), which some might argue constitutes a performative act of resistance. However, performing a René Marqués play in the Sala Teatro René Marqués hardly issues much of a critique. All of this brings me back to the notion of theatrical space and the question of spaces for alternative theater. Part of what was interesting about the work of La Perilla y El Kibutz was the way that they exploded the need for a theater, demonstrating that their primary need (teatro de urgencia) was to simply be seen and heard, to be uncensored, for the artists to have access to the public and for the public to have access to the artists. I will be looking to these young teatreras and teatreros to create meaningful and incendiary theater on stages and in public spaces in Puerto Rico, despite whatever permission they have been granted or denied, exercising not only a Puerto Rican's right to freedom but an individual's right to be alive.

University of California, San Diego 